\title{
Micropropagation of lavender: a protocol for production of plantlets
}

\author{
Jana Koefender ${ }^{1 *} \mathbb{D}$; Candida Elisa Manfio ${ }^{2} \mathbb{D}$; Juliane N Camera ${ }^{1} \mathbb{D}$; André Schoffel ${ }^{1} \mathbb{D}$; Diego Pascoal \\ Golle ${ }^{1}$ id
}

${ }^{1}$ Universidade de Cruz Alta (Unicruz), Cruz Alta-RS, Brasil; jkoefender@unicruz.edu.br (author for correspondence); ju_camera@yahoo. com.br; andre-schoffel@hotmail.com; dgolle@unicruz.edu.br; ${ }^{2}$ Empresa de Pesquisa Agropecuária e Extensão Rural de Santa Catarina (Epagri-SC), Ituporanga-SC, Brasil; candidamanfio@gmail.com

\begin{abstract}
Lavender (Lavandula dentata) has several medicinal applications, both in the fresh form and after industrial processing. Productivity increase could be obtained through the mass propagation, expanding the possibility of obtaining raw material for production of essential oil. The objective of this work was to develop a micropropagation protocol from explants obtained from seeds. Aspects of in vitro germination, multiplication, elongation and rooting were evaluated and, in sequence, the acclimatization process as well. The in vitro germination of lavender seeds can be obtained using a medium composed of agar and water. For multiplication, the use of MS medium (Murashige \& Skoog, 1962) added with 5.0 $\mu$ M 6-benzylaminopurine to the nutrient medium is the most appropriate. For elongation and rooting, the use of growth regulators is unnecessary. Acclimatization can be obtained directly by transferring the explant to plastic bags with substrate, kept in a greenhouse. It was possible to develop a protocol for the in vitro cultivation (establishment, multiplication, elongation, rooting and acclimatization) of lavender from explants of seed origin.
\end{abstract}

Keywords: Lavandula dentata, in vitro cultivation, essential oils, mass multiplication.

\section{RESUMO}

Micropropagação de lavanda: um protocolo para produção de mudas

A lavanda (Lavandula dentata) possui diversas aplicações medicinais, tanto in natura como após processamento industrial. $\mathrm{O}$ incremento à produtividade pode ser obtido por meio da propagação massal, ampliando a possibilidade de obtenção de matéria prima para a produção de óleo essencial. O objetivo deste trabalho foi desenvolver um protocolo de micropropagação a partir de explantes obtidos de sementes. Foram avaliados aspectos da germinação, multiplicação, alongamento e enraizamento in vitro e, em seguida, o processo de aclimatização das mudas. A germinação in vitro de lavanda pôde ser obtida apenas com a utilização do meio composto por ágar e água. Para a multiplicação, o uso de meio MS (Murashige \& Skoog, 1962) acrescido de 5,0 $\mu \mathrm{M}$ de 6-benzilaminopurina ao meio nutritivo é o mais apropriado. Para o alongamento e enraizamento, a utilização de reguladores de crescimento é dispensável. A aclimatização pode ser obtida diretamente com a transferência do explante para sacos plásticos com substrato, mantidos em casa de vegetação. Foi possível desenvolver um protocolo para o cultivo in vitro (estabelecimento, multiplicação, alongamento, enraizamento e aclimatização) de lavanda a partir de explantes de sementes.

Palavras-chave: Lavandula dentata, cultivo in vitro, óleos essenciais, multiplicação massal.

\section{Received on February 9, 2021; accepted on August 19, 2021}

$\mathrm{O}$ ver 25,000 plant species with medicinal properties are used worldwide. Those uses include everything from ethnobotanical practices to the production of medicines. Currently, the herbal medicine production chain grows more (around 15\%) than the production of synthetic medicines (4\%) (Rodrigues, 2016). The global market for vegetable essential oils grew by 7.5 billion dollars a year through 2018 . In addition, lavender oils represent an important share of this market, with 1,500 tons of oil per year (Wells et $a l ., 2018)$. The genus Lavandula has essential oils of medicinal properties related to the control of acne, cramps, flatulence, in addition to the relaxing and also antibacterial actions. Its application in perfumery is relevant, as well as the landscape use of Lavandula spp. for the beauty of the plantations and its pleasant aroma. The leading world producers are France, Bulgaria, Great Britain, Australia and Russia (Adamuchio et al., 2017). Lavender essential oil has more than 100 constituents (Devasigamani et $a l ., 2020)$ and, among other properties, is a natural preservative (tested on several microorganisms), antimicrobial, antioxidant, anti-inflammatory and pest control (Wells et al., 2018).

In Brazil, lavender (Lavandula dentate) is the most cultivated species and like other species of the genus, it is known for its medicinal and aromatic potential. Studies have demonstrated the application of hydroalcoholic extract of this species with anti-inflammatory properties (Algieri et al., 2016). Nevertheless, the hepatoprotective and antioxidant action of lavender has been 
demonstrated (Pereira et al., 2019). Martins et al. (2019) identified more than 20 compounds in the essential oil of this species, which confirms its potential for the industry. Among the compounds, fenchone, eucalyptol and camphor stand out (Martins et al., 2019).

The Brazilian demand for Lavandula spp. has aroused the interest of farmers, as there is a market, but few commercial crops in the country. The seminal propagation is difficult especially because of the high cost of importing seeds, but also because of the frequent need of a previous treatment to overcome dormancy. Seeds of the lavender genus have slow germination rates and heterogeneous growth, which is a problem to improve industrial production with homogeneity in the composition of oils. As a result, lavender growers around the world show preference for vegetative propagation (clones), material for uniform production (Wells et al., 2018; Rodrigues et al., 2020).

Some researches about the in vitro cultivation of Lavandula spp. have been carried out, to produce homogeneous plant material. Studies with $L$. dentata were carried out, but with different explant sources when compared to our study. Jordan et al. (1998) and Echeverrigaray et al. (2005) obtained micropropagation using nodal segments of adult plants as explants. Machado et al. (2011) developed a protocol for the regeneration of $L$. dentata by shoot tips. With other species of the Lavandula genus, a protocol for $L$. angustifolia in vitro cultivation from young segments was possible from seeds' germination. Different light sources and nutritional media were used (Machado et al., 2013; Oliveira et al., 2019). Also, for L. angustifolia, cultivation was possible from leaf explants, via indirect organogenesis (Devasigamani et al., 2020). So, the in vitro production can contribute as it allows the multiplication to obtain plantlets that make the culture feasible (Adamuchio et al., 2017). Guo et al. (2014) report the importance of the micropropagation technique for mass production of plants that may be of industrial interest. In addition, with the increase in the demand for new plant products, tissue culture can contribute to obtain bioactive compounds of interest (Dias et al., 2016) from the in vitro cultures.

The objective of this work was to develop a protocol for the micropropagation of lavender from explants of seed origin. Here, we have developed a protocol involving the stages of germination, establishment, multiplication, elongation and acclimatization.

\section{MATERIAL AND METHODS}

The experiment was conducted at the Plant Tissue Culture Laboratory at the University of Cruz Alta (Cruz Alta-RS), from February to December 2019. The explants are originated from commercial seeds (Feltrin ${ }^{\circledR}$ ) obtained from an agricultural store. The steps of the experiments are described below.

\section{In vitro germination}

For the in vitro germination, an experiment was carried out in a completely randomized design, with four treatments and 20 replicates. The use of different culture media was evaluated, where one was composed only of water/agar $\left(7 \mathrm{~g} \mathrm{~L}^{-1}\right)$; and the other of MS medium (Murashige \& Skoog, 1962) at the concentrations of $25 \%, 50 \%$ and $100 \%$ (in which the agar was added in the same concentration as mentioned above). The experimental unit consisted of $300 \mathrm{~mL}$ flasks, containing $40 \mathrm{~mL}$ nutrient medium and five lavender seeds (Lavandula dentata) (Feltrin ${ }^{\circledR}$ commercial seeds), totaling 80 experimental units and 400 seeds. Prior to inoculation, the seeds were soaked in a solution of gibberellic acid $\left(\mathrm{GA}_{3}\right)$ at $1.5 \mathrm{mg} \mathrm{L}^{-1}$ for 48 hours to increase and accelerate germination according to reports for the genus (Aoyama et al., 1996; Oliveira et al., 2019). Next, seeds went through a disinfestation process, which occurred in a laminar flow cabinet in the following sequence: 1 minute in $70 \%$ alcohol, 20 minutes in $4 \%$ sodium hypochlorite, and triple washing with sterile distilled water. After disinfestation and inoculation in the nutrient medium, the experimental units were kept in a growth room (the characteristics of the growth room will be described in a specific topic). At 15 days, the germination percentage was evaluated.

\section{Multiplication}

For the in vitro multiplication, the experiment was carried out in a completely randomized design, using a $2 \times 3$, bifactorial scheme, where levels of " $A$ " factor was represented by the presence or absence of 1-alphanaphthalenoacetic acid (NAA, 0 and $1.0 \mu \mathrm{M}$ ) and the levels of "B" factor were represented by three different concentrations of cytokinin (BAP, 6-benzylaminopurine): $0 ; 5.0 ; 10.0$ $\mu \mathrm{M}$; totaling six treatments and ten replicates, each composed of a $200 \mathrm{~mL}$ flask containing two explants (nodal segments) and $20 \mathrm{~mL}$ culture medium. Thus, a total of 60 experimental units and 120 explants were analyzed. After 60 days of cultivation, the following variables were evaluated: number of shoots per explant, shoot length $(\mathrm{cm})$, leaf number, hyperhydricity (\%) and callus formation (\%).

\section{Elongation and rooting}

Regarding the in vitro elongation and rooting of the explants in vitro (1 $\mathrm{cm}$ long nodal segments) as well as the acclimatization, the experiments were conducted in a completely randomized design. Two growth regulators, IAA (indoleacetic acid) and $\mathrm{GA}_{3}$ (gibberellic acid) were tested at concentrations of $0,5,0$ and $10,0 \mu \mathrm{M}$, totaling nine treatments, with 10 replicates, each composed of a $200 \mathrm{~mL}$ flask containing two explants and $20 \mathrm{~mL}$ culture medium. For the elongation, after 60 days in vitro cultivation, root formation (\%), hyperhydricity (\%), callus formation $(\%)$, leaf number, shoot length $(\mathrm{cm})$ and number of shoots per explant were evaluated.

\section{Acclimatization}

In relation to the acclimatization phase, four treatments were tested, in which the experimental units remained in the growth room for the first 10 days, namely: permanence in the cultivation flask (in culture medium) sealed with aluminum foil; permanence in a culture flask (in culture medium) sealed with plastic film; maintain in the cultivation 
flask (in culture medium) without sealing; direct transplant to substrate packed in plastic bags (the substrate used was Carolina Soil ${ }^{\circledR}$ class XVI). Afterwards, regardless of the previous treatments, all explants were transferred to disposable plastic cups containing autoclaved substrate, kept in a growth room for one week and, subsequently transferred to $300-\mathrm{mL}$ plastic bags with substrate containing one plant and transferred to greenhouse with controlled temperature and irrigation. 30 days after transferring the explants to the greenhouse, the survival (\%) and length $(\mathrm{cm})$ of the plantlets were evaluated.

In experiments in which the MS medium was used, $100 \mathrm{mg} \mathrm{L}^{-1}$ of inositol, $30 \mathrm{~g} \mathrm{~L}^{-1}$ of sucrose and $7 \mathrm{~g} \mathrm{~L}^{-1}$ of agar were added (except in the germination experiment with agar-water treatment). The $\mathrm{pH}$ of the media was adjusted to 5.8 and sterilized for 20 minutes at $121^{\circ} \mathrm{C}$ and $1.5 \mathrm{~atm}$ pressure. The conditions of the growth room (all experiments) were characterized by $25 \pm 3^{\circ} \mathrm{C}$ temperature and $16 \mathrm{~h}$ photoperiod, obtained with daylight-type fluorescent lamps, with $40 \mu \mathrm{mol} \mathrm{m}^{-2} \mathrm{~s}^{-1}$ light intensity.

\section{Statistical analysis}

The normality of the errors was tested by the Kolmogorov-Smirnov test and the homogeneity of variances by the test of Bartlett. When necessary, for analysis purposes, the data were transformed by the $\sqrt{x+0,5}$ function, however, the exposed data were the originals. Afterwards, the results were submitted to Analysis of Variance and when the " $F$ " value was significant, the multiple comparison of the means was performed using the Tukey test at 5\% probability of error. The analyses were performed with the aid of the SISVAR $\AA$ statistical software (Ferreira, 2011).

\section{RESULTS AND DISCUSSION}

\section{Germination}

For the lavender seed germination experiment, no differences were observed among the tested treatments; the use of nutritive medium (MS medium at 25,50 or $100 \%$ ) or just water-agar was indifferent. Therefore, the use of water-agar is indicated at this stage for being more economical. Also, the average germination obtained was $80 \%$ : medium water-agar $(81 \%)$, MS medium at $25 \%(80 \%), 50 \%(79 \%)$ and $100 \%(80 \%)$. Considering that the literature reports that lavender seeds have a slow germination process, and a low germination percentage in tissue culture (Panizza \& Tognoni, 1991), the results in this study demonstrated a good germination percentage and the in vitro establishment of the species. In addition, studies of culture media that promote in vitro germination are important, to maximize the germination rate (Rosa et al., 2012). In culture media where the concentration of nutrients is reduced, the responses tend to be of lesser magnitude compared to those in which there is no such reduction. In this study, it appears that the nutrients absence did not harm the germination of lavender seeds, which can directly result in the minimization of cultivation costs. Results of studies with L. angustifolia (a species of the same genus) with the use of $\mathrm{GA}_{3}$ for in vitro germination have also shown satisfactory results, but, still, slightly less than $80 \%$ (Oliveira et al., 2019).

\section{Multiplication}

Regarding multiplication, for all evaluated variables in this experiment, interaction was observed between the different concentrations of NAA and BAP used. In relation to number of shoots per explant, the greatest increase in multiplication occurred when $5,0 \mu \mathrm{M}$ BAP was used in the absence of NAA, with the formation of 9.05 shoots per explant. A study with the species of the same genus Lavandula angustifolia obtained rates of 1.9 to 3.3 sprouts per explant (in the LS medium with $1.0 \mu \mathrm{M}$ BAP), lower than that obtained in this study (Machado et al., 2013).

In relation to the shoot length, the best result was observed when growth regulators $(2.29 \mathrm{~cm})$ were not used, possibly because the

Table 1. Number of shoots per explant, shoot length $(\mathrm{cm})$, leaf number, hyperhidricity $(\%)$ and callus formation (\%) of lavender plants (Lavandula dentata) submitted to different BAP and NAA concentrations in vitro cultivation. Cruz Alta, Unicruz, 2015.

\begin{tabular}{|c|c|c|c|c|c|}
\hline \multirow{2}{*}{ Evaluated variables } & \multirow{2}{*}{ NAA } & \multicolumn{4}{|c|}{ BAP } \\
\hline & & $\mathbf{0} \boldsymbol{\mu M}$ & $5.0 \mu \mathrm{M}$ & $10.0 \mu \mathrm{M}$ & Means \\
\hline \multirow{4}{*}{ Shoots per explant $\left(\mathrm{n}^{\circ}\right)$} & $0.0 \mu \mathrm{M}$ & $2.00 \mathrm{a} \mathrm{B}$ & 9.05 a A & 4.70 a B & 5.25 \\
\hline & $1.0 \mu \mathrm{M}$ & $2.10 \mathrm{a} \mathrm{A}$ & $3.95 \mathrm{~b} \mathrm{~A}$ & $1.45 \mathrm{~b} \mathrm{~B}$ & 2.50 \\
\hline & Means & 2.05 & 6.50 & 3.07 & \\
\hline & CV $(\%)$ & \multicolumn{4}{|c|}{38} \\
\hline \multirow{4}{*}{ Shoot length (cm) } & $0 \mu \mathrm{M}$ & $2.29 \mathrm{a} \mathrm{A}$ & 0.75 a B & $1.31 \mathrm{a} \mathrm{AB}$ & 1.45 \\
\hline & $1.0 \mu \mathrm{M}$ & $1.30 \mathrm{a} \mathrm{A}$ & $1.07 \mathrm{a} \mathrm{A}$ & $1.04 \mathrm{a} \mathrm{A}$ & 1.14 \\
\hline & Means & 1.79 & 0.91 & 1.17 & \\
\hline & $\mathrm{CV}(\%)$ & \multicolumn{4}{|c|}{26} \\
\hline \multirow{4}{*}{ Leaf $\left(n^{\circ}\right)$} & $0 \mu \mathrm{M}$ & $13,5 \mathrm{a} A B$ & $10,1 \mathrm{~b} \mathrm{~B}$ & 15,5 a A & 13,03 \\
\hline & $1.0 \mu \mathrm{M}$ & 11,7 a B & 16,2 a A & 13,9 a $\mathrm{AB}$ & 13,93 \\
\hline & Means & 12,6 & 13,15 & 14,7 & \\
\hline & CV $(\%)$ & \multicolumn{4}{|c|}{14} \\
\hline \multirow{4}{*}{ Hyperhidricity (\%) } & $0 \mu \mathrm{M}$ & $1.0 \mathrm{a} \mathrm{A}$ & $7.0 \mathrm{a} \mathrm{B}$ & $9.0 \mathrm{a} \mathrm{B}$ & 5.67 \\
\hline & $1.0 \mu \mathrm{M}$ & $1.0 \mathrm{a} \mathrm{A}$ & $6.0 \mathrm{~b} \mathrm{~B}$ & $6.0 \mathrm{~b} \mathrm{~B}$ & 4.33 \\
\hline & Means & 1.0 & 6.5 & 7.5 & \\
\hline & CV $(\%)$ & \multicolumn{4}{|c|}{73} \\
\hline \multirow{4}{*}{ Callus formation (\%) } & $0 \mu \mathrm{M}$ & $10 \mathrm{a} A$ & 90 a B & $50.2 \mathrm{a} A B$ & 50.06 \\
\hline & $1.0 \mu \mathrm{M}$ & $60 \mathrm{~b} \mathrm{~A}$ & 60 a A & 80 a A & 66.6 \\
\hline & Means & 35 & 75 & 65.1 & \\
\hline & CV $(\%)$ & \multicolumn{4}{|c|}{67} \\
\hline
\end{tabular}

*Means followed by uppercase letter in the line and lowercase letter in the column are not different from each other by the Tukey test, $\mathrm{p}<0.05$. 


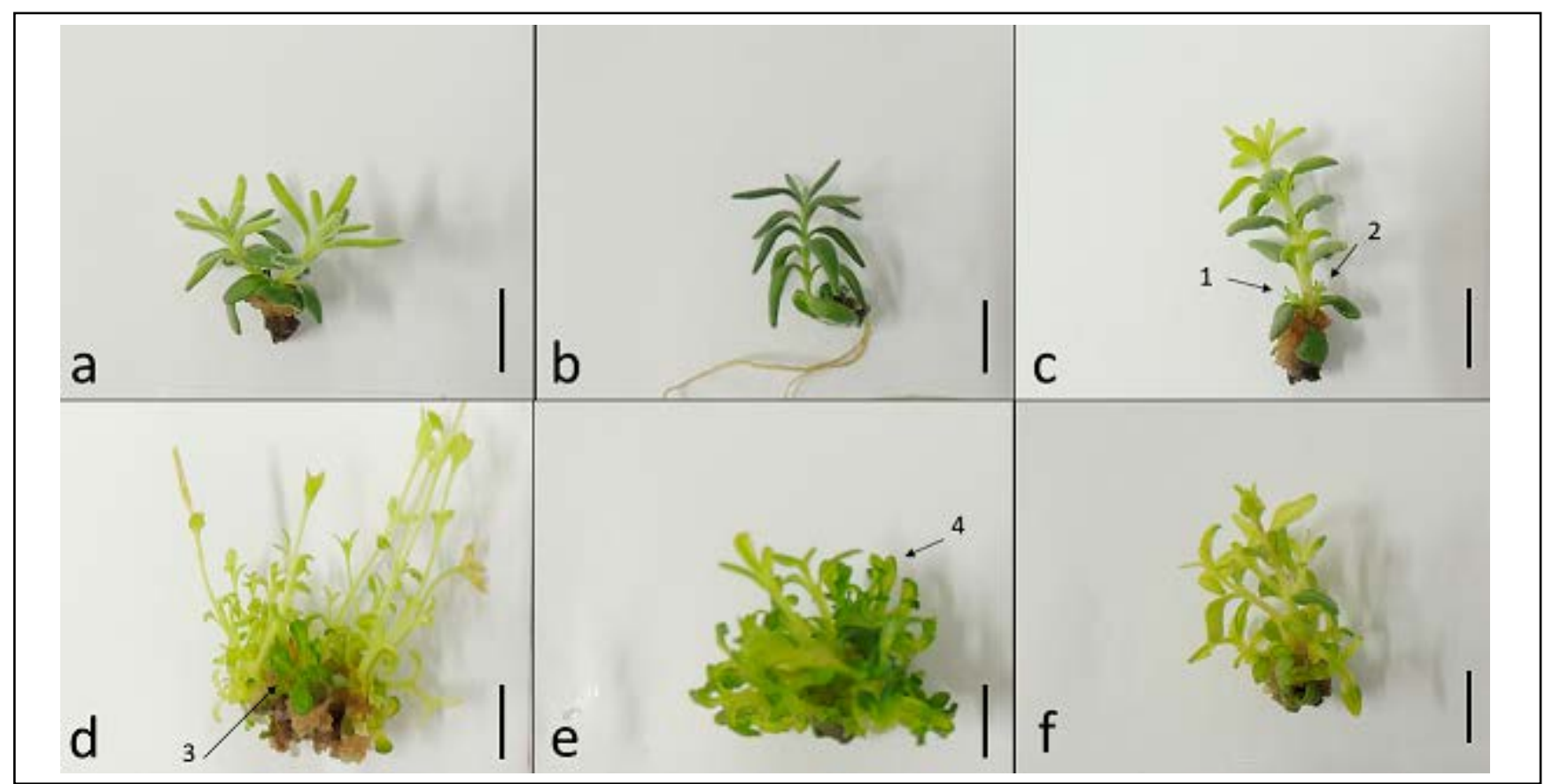

Figure 1. Overall aspect of in vitro multiplication of Lavandula dentata. The treatments refer to combinations between NAA and BAP ( $\mu \mathrm{M})$ namely: a) $0-0$; b) $1.0-0$; c) $0-5.0$; d) $1-5.0$; e) $0-10.0$; f) 1-10.0. In figure "c", the arrows point to the shoots that appear at the base of the explant. In figures "d" and "e", the arrows show the hyperhydricity aspect of the treatments. Side bars = 1.0 cm. Cruz Alta, Unicruz, 2015.

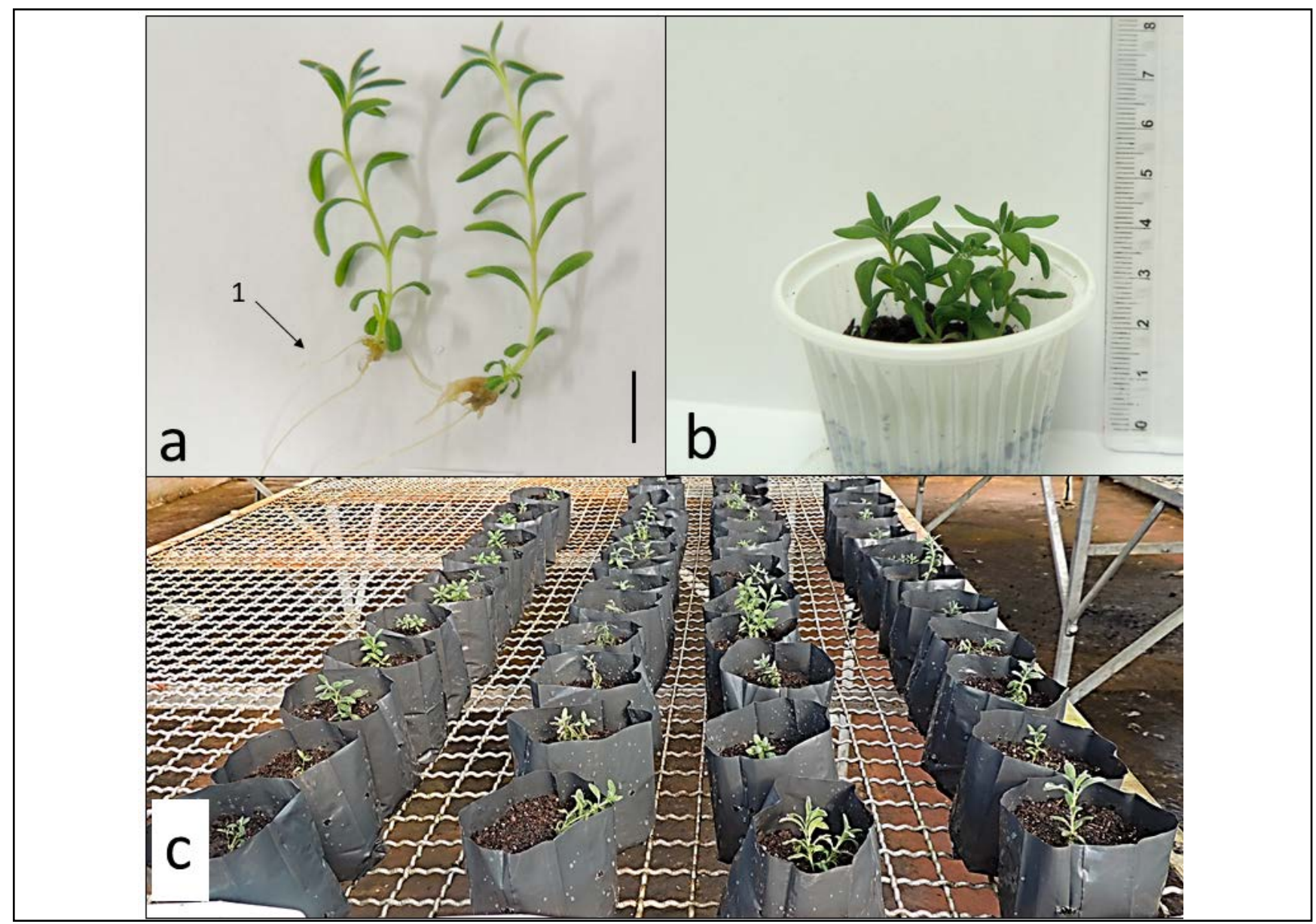

Figure 2. Overall aspect of the elongation of lavender plants (Lavandula dentata) (a) in which the arrows point to the root formation; from the beginning of the acclimatization process in the cultivation room (b); development in the greenhouse (c). Bar $=1.0 \mathrm{~cm}$. Cruz Alta, Unicruz, 2015. 
Table 2. Number of shoots per explant, shoot length (cm), leaf number, callus formation (\%), hyperhidricity (\%) and root formation (\%) of lavender plants (Lavandula dentata) submitted to different concentrations of $\mathrm{GA}_{3}$ and IAA in vitro cultivation. Cruz Alta, Unicruz, 2015.

\begin{tabular}{|c|c|c|c|c|c|}
\hline \multirow{2}{*}{ Evaluated variables } & \multirow{2}{*}{ IAA } & \multicolumn{4}{|c|}{ GA3 } \\
\hline & & $\mathbf{0 \mu M}$ & $5.0 \mu \mathrm{M}$ & $10.0 \mu \mathrm{M}$ & Means \\
\hline \multirow{5}{*}{ Shoots per explant $\left(\mathrm{n}^{\circ}\right)$} & $0.0 \mu \mathrm{M}$ & $2.00 \mathrm{Aa}$ & $2.45 \mathrm{Aa}$ & $3.77 \mathrm{Aa}$ & 2.74 \\
\hline & $0.5 \mu \mathrm{M}$ & $1.10 \mathrm{Ba}$ & $1.55 \mathrm{ABa}$ & $1.85 \mathrm{Aa}$ & 1.50 \\
\hline & $1.0 \mu \mathrm{M}$ & $1.95 \mathrm{Aa}$ & $2.11 \mathrm{Aa}$ & $2.08 \mathrm{Aa}$ & 2.05 \\
\hline & Means & 1.68 & 2.04 & 2.57 & \\
\hline & $\mathrm{CV}(\%)$ & & 26 & & \\
\hline \multirow{5}{*}{ Shoot length $(\mathrm{cm})$} & $0.0 \mu \mathrm{M}$ & $1.85 \mathrm{Bb}$ & $3.00 \mathrm{Aa}$ & $3.59 \mathrm{Aa}$ & 2.81 \\
\hline & $0.5 \mu \mathrm{M}$ & $2.10 \mathrm{Ab}$ & $2.65 \mathrm{Aa}$ & $2.40 \mathrm{Aab}$ & 2.38 \\
\hline & $1.0 \mu \mathrm{M}$ & $3.09 \mathrm{Aa}$ & $2.67 \mathrm{Aa}$ & $2.92 \mathrm{Ab}$ & 2.89 \\
\hline & Means & 2.35 & 2.77 & 2.97 & \\
\hline & $\mathrm{CV}(\%)$ & & 29 & & \\
\hline \multirow{5}{*}{ Leaf $\left(n^{\circ}\right)$} & $0.0 \mu \mathrm{M}$ & $13.50 \mathrm{Aab}$ & $15.90 \mathrm{Aa}$ & $17.27 \mathrm{Aa}$ & 15.56 \\
\hline & $0.5 \mu \mathrm{M}$ & $12.40 \mathrm{Ab}$ & $14.60 \mathrm{Aa}$ & $16.20 \mathrm{Aa}$ & 14.40 \\
\hline & $1.0 \mu \mathrm{M}$ & $16.91 \mathrm{Aa}$ & $16.22 \mathrm{Aa}$ & $16.33 \mathrm{Aa}$ & 16.49 \\
\hline & Means & 14.27 & 15.57 & 16.60 & \\
\hline & $\mathrm{CV}(\%)$ & & 24 & & \\
\hline \multirow{5}{*}{ Callus formation (\%) } & $0.0 \mu \mathrm{M}$ & 10.00 & 0.50 & 0.73 & $3.74 \mathrm{~A}$ \\
\hline & $0.5 \mu \mathrm{M}$ & 0.30 & 0.40 & 0.60 & $0.43 \mathrm{~A}$ \\
\hline & $1.0 \mu \mathrm{M}$ & 0.55 & 0.22 & 0.67 & $0.48 \mathrm{~A}$ \\
\hline & Means & $3.62 \mathrm{~A}$ & $0.37 \mathrm{~A}$ & $0.66 \mathrm{~A}$ & \\
\hline & $\mathrm{CV}(\%)$ & & 25 & & \\
\hline \multirow{5}{*}{ Hyperhidricity (\%) } & $0.0 \mu \mathrm{M}$ & 10.00 & 0.20 & 0.27 & 3.49 \\
\hline & $0.5 \mu \mathrm{M}$ & 0.10 & 0.20 & 0.20 & 0.17 \\
\hline & $1.0 \mu \mathrm{M}$ & 0.00 & 0.22 & 0.33 & 0.19 \\
\hline & Means & 3.37 & 0.21 & 0.27 & \\
\hline & $\mathrm{CV}(\%)$ & & 30 & & \\
\hline \multirow{5}{*}{ Root formation (\%) } & $0.0 \mu \mathrm{M}$ & $20.00 \mathrm{Aa}$ & $0.30 \mathrm{Ba}$ & $0.18 \mathrm{Ba}$ & 6.83 \\
\hline & $0.5 \mu \mathrm{M}$ & $0.40 \mathrm{Ab}$ & $0.30 \mathrm{Aa}$ & $0.30 \mathrm{Aa}$ & 0.33 \\
\hline & $1.0 \mu \mathrm{M}$ & $0.09 \mathrm{Ab}$ & $0.33 \mathrm{Aa}$ & $0.33 \mathrm{Aa}$ & 0.25 \\
\hline & Means & 6.83 & 0.31 & 0.27 & \\
\hline & $\mathrm{CV}(\%)$ & & 30 & & \\
\hline
\end{tabular}

*Means followed by the same uppercase letter in the line and the same lowercase letter in the column are not different from each other by the Tukey test, $\mathrm{p}<0.05$.

morphogenic routes are not channeled towards multiplication, but towards the development of the explant; the number of leaves was higher when using the combination of $1,0 \mu \mathrm{M}$ NAA and 5,0 $\mu \mathrm{M}$ BAP. Hyperhydricity was observed as the concentration of BAP increased, but in the later stages it did not compromise development and acclimatization, nor did it affect the multiplication of the explants. Hyperhydricity is a physiological problem of excessive hydration and be seen in Figure 1.

It can be considered that the data obtained in the experiment show the adequate in vitro multiplication rates obtained as this is the most relevant data in this step of the study, mainly due to the multiplication rate. The highest rate was 9.05 shoots per explant. Some studies with species of the same genus have also obtained favorable results with the use of cytokinins, however, not approaching the average obtained in this study. In L. coronopifolia, the use of BAP allowed to obtain 3.6 shoots per explant (Khateeb et al., 2017). On the other hand, for L. angustifolia, also with cytokinin supplementation (BAP), Vinh et al. (2017) obtained 3.06 shoots per explant. It is important to mention that the calluses observed in this treatment were small and did not compromise multiplication; likewise, hyperhydricity only in the most basal part of the explant did not compromise the transfer to the culture media of the next stages and development.

\section{Elongation and rooting}

On the elongation phase, there was interaction between the different concentrations of IAA and $\mathrm{GA}_{3}$ for number of shoots per explant, shoot length, leaf number and root formation (Table 2). For the number of shoots, using 0 and $1,0 \mu \mathrm{M}$ of IAA did not show any differences in the different concentrations of $\mathrm{GA}_{3}$ (Table 2), ranging the number of shoots per explant from 1.10 to 3.77. The use of IAA at $0,5 \mu \mathrm{M}$, alone or with $5.0 \mu \mathrm{M} \mathrm{GA}_{3}$, reduced the number of shoots.

For shoot length, at $0 \mu \mathrm{M}$ of IAA and $10.0 \mu \mathrm{M}$ of $\mathrm{GA}_{3}$, a length of 3.59 $\mathrm{cm}$ was achieved. The number of leaves in lavender was not influenced by the different concentrations of $\mathrm{GA}_{3}$. An increase in the number of leaves was observed at concentrations $0 \mu \mathrm{M}$ of $\mathrm{GA}_{3}$, as the concentrations of IAA were incremented. There was no difference between the treatments tested for callus formation (Table 2). The highest percentage of lavender root formation was obtained at the concentration of 0 $\mu \mathrm{M}$ IAA and $0 \mu \mathrm{M} \mathrm{GA}_{3}$. The greatest hyperhydricity was observed in the absence of growth regulators, however, in the best treatment for elongation (10 
Table 3. Survival and plant height of lavender plants (Lavandula dentata) in different ways for acclimatization (different cultivation flasks seals with subsequent passage to plastic cups or direct passage to bags). Cruz Alta, Unicruz, 2015.

\begin{tabular}{lcc}
\hline Treatments & $\begin{array}{c}\text { Survival } \\
(\mathbf{\%})\end{array}$ & $\begin{array}{c}\text { Plant height } \\
\text { (cm) }\end{array}$ \\
\hline Cultivation flask sealed with aluminum foil & $46.15 \mathrm{~b}^{*}$ & $2.23 \mathrm{a}$ \\
Cultivation flask sealed with plastic film & $93.33 \mathrm{a}$ & $3.96 \mathrm{a}$ \\
Cultivation flask without sealing & $80.00 \mathrm{ab}$ & $3.45 \mathrm{a}$ \\
Plastic bag for seedlings direct transplant & $83.33 \mathrm{ab}$ & $3.20 \mathrm{a}$ \\
\hline CV $(\%)$ & 15 & 36 \\
\hline
\end{tabular}

*Means followed by the same letter are not different from each other by the Tukey test, $\mathrm{p}<0.05$.

$\mu \mathrm{M}$ of $\mathrm{GA}_{3}$ ) it was only $0.27 \%$ (Table 2 ).

Works carried out by Machado et al. (2013) demonstrate that on the rooting percentage of lavender plants, the number of main roots per micro cuttings was higher when auxin was not added to the culture medium, thus, a reduction in the number of roots in the presence of IBA and NAA was observed. In preliminary studies, different responses were also observed in the induction of in vitro rooting of lavender plants with the addition of plant regulators. The overall aspect of the elongation and acclimatization can be seen in Figure 2 .

\section{Acclimatization}

In acclimatization process of lavender plants, no statistical difference was observed on the height of the plants, testing different treatments. However, the treatments differed in terms of survival. So, all evaluated treatments were recommended, except the use of cultivation flasks wrapped with aluminum foil. We observed that, although the height of the plants that survived showed no statistical difference between the treatments tested, the percentage of survival was higher when the cultivation flasks were wrapped with plastic film, however it was indifferent whether we used a plastic cup or plastic bag (Table 3).

For the in vitro cultivation of lavender from explants of seed origin, the germination process can be performed using a medium composed only of agar and water. For the multiplication, the use of MS medium added with 5,0 $\mu \mathrm{M}$ BAP allows to achieve a greater number of shoots, therefore showing the occurrence of hyperhydricity and calluses in some shoots but however, still offering the highest rate of propagation. It should be mentioned that additional studies should be carried out in order to reduce hyperhydricity. It is important to mention that the observed calluses were small and at the base of the explants, not preventing the fragmentation for subculture in the elongation experiments; in the same way, hyperhydricity was in the basal portion of the explants, barely noticeable, not preventing the continuation of cultivation either. For better acclimatization, the process should be started in cultivation flasks sealed with plastic film, and only later transferred to the greenhouse. It was possible to obtain a complete protocol for the micropropagation of Lavandula dentata from explants of seed origin, from in vitro cultivation to acclimatization.

\section{ACKNOWLEDGEMENTS}

To the National Council for Scientific and Technological Development for financing the scholarship (CNPq). To Economics Developing, Science and Technology General Office (SICT$\mathrm{RS}$ ) and World Bank (BIRD), to the Coordination for the Improvement of Higher Education Personnel (CAPES), to Research Support Foundation of the State of Rio Grande do Sul for the scholarships (FAPERGS).

\section{REFERENCES}

ADAMUCHIO, LG; DESCHAMPS, C;
MACHADO, MP. 2017. Aspectos gerais sobre a cultura da Lavanda (Lavandula spp.). Revista Brasileira de Plantas Medicinais 19: 483-490.

ALGIERI, F; RODRIGUEZ-NOGALES, A; VEZZA, T; GARRIDO-MESA, J; GARRIDOMESA, N; UTRILLA, MP; GONZÁLEZTEJERO, MR; CASARES-PORCEL, M; MOLERO-MEZA, J; CONTRERAS, MDM; SEGURA-CARRETERO, A; PÉREZPALACIO, J; DIAZ, C; VERGARA, N; VICENTE, F; RODRIGUEZ-CABEZAS, ME; GALVEZ, J. 2016. Anti inflamatory activity of hidroalcoholic extracts of Lavandula dentata L. and Lavandula stoechas L. Journal of Ethnopharmacology 190: 142-158.

AOYAMA, EM; ONO, EO; FURLAN, MR. 1996. Estudo da germinação de sementes de lavanda (Lavandula angustifolia Miller). Scientia Agricola 53: 2-3.

DEVASIGAMANI, L; DEVARAJAN, R; LOGANATHAN, R; RAFATH, H; PADMAN, M; MV, GR; GIRIDHAR, L; HC, C; KUPPAN, N. 2020. Lavandula angustifolia L. plants regeneration from in vitro leaf explantsderived callus as conservation strategy. Biotecnología 20: 76-82.

DIAS, MI; SOUSA, MJ; ALVES, RC; FERREIRA, ICFR. 2016. Exploring plant tissue culture to improve the production of phenolic compounds: a review. Industrial Crops and Products 82: 9-22.

ECHEVERRIGARAY, S; BASSO, R;ANDRADE, LB. 2005. Micropropagation of Lavandula dentata from axillary buds of field-grown adult plants. Biologia Plantarum: 49: 439-334.

FERREIRA, DF. 2011. Sisvar: a computer statistical analysis system. Ciência e Agrotecnologia 35: 1039-1042.

GUO, L; XUE, F; GUO, J; NA, R. 2014. Plant tissue culture: a recent progress and potential applications. Journal of Agricultural Science and Technology 15: 2088-2095.

JORDAN, AM; CALVO, MC; SEGURA, J. 1998. Micropropagation of adult Lavandula dentata plants. The Journal of Horticultural Science and Biotechnology 73: 93-96.

KHATEEB, WA; KANAAN, R; EL-ELIMAT, T; ALU'DATT, M; LAHHAM, J; EL-OQLAH, A. 2017. In vitro propagation, genetic stability and secondary metabolite analysis of wild lavender (Lavandula coronopifolia Poir). Horticulture, Environment, and Biotechnology 58: 393-405.

MACHADO, MP; CIOTTA, MN; DESCHAMPS, C; ZANETTE, F; CÔCCO, LC; BIASI, LA. 2013. Propagação in vitro e caracterização química do óleo essencial de Lavandula angustifolia cultivada no Sul do Brasil. Ciência Rural 43: 283-289.

MACHADO, MP; SILVA, ALL; BIASI, LA. 2011. Effect of plant growth regulators on in vitro regeneration of Lavandula dentata L. shoot tips. Journal of Biotechnology and Biodiversity 2: 28-31.

MARTINS, RP; GOMES, RAS; MALPASS, ACG; OKURA, MH. 2019. Chemical characterization of Lavandula dentata $\mathrm{L}$. essential oils grown in Uberaba-MG. Ciência Rural 49: 1-7.

MURASHIGE, T; SKOOG, F. 1962. A revised 
medium for rapid growth and bioassays with tobacco tissue culture. Physiologia Plantarum 15: 473-497.

OLIVEIRA, RC; ASMAR, SA; SILVA, HFJ; MORAIS, TP; LUZ, JMQ. 2019. Regulators, culture media and types of lights in vitro lavander culture. Ciência Rural 49: 1-7.

PANIZZA, M; TOGNONI, F. 1991. Micropropagation of Lavandin (Lavandula officinalis Chaix x Lavandula latifolia Villars cv. 'Grosso'). In: BAJAJ, YPS (ed). Biotechnology in Agriculture and Forestry. New York: Spring. p. 295-305.

PEREIRA, OR; MACIAS, RIR; DOMINGUES,
MRM; MARIN, JJG; CARDOSO, SM. 2019. Hepatoprotection of Mentha aquatica L., Lavandula dentata L., and Leonurus cardiaca L. Antioxidants 267:1-13.

RODRIGUES, WC. 2016. Competitividade e mudança institucional na cadeia produtiva de plantas medicinais no Brasil. Interações 17: 267-277.

RODRIGUES, DB; RADKE, AK; SOMMER, LR; ROSA, DSB; SCHUCH, MW; ASSIS, AM. 2020. Quality of light and indolbutiric acid in vitro rooting of lavander. Ornamental Horticulture 26: 89-94.

ROSA, FC; REINIGER, LRS; GOLLE, DP;
MUNIZ, MFB; CURTI, AR. 2012. Superação da dormência e germinação in vitro de sementes de bracatinga (Mimosa scabrella Bentham). Semina: Ciências Agrárias 33: 1021-1026.

VINH, DT; HOA, MT; KHAI, PC; MINH, TV. 2017. Micropropagation of lavender (Lavandula angustifolia). Journal of Innovations in Pharmaceutical and Biological Sciences 4: 7-11.

WELLS, R; TRUONG, F; ADAL, AM. 2018. Lavandula essential oils: a current review of applications in medicinal, food and cosmetic industries of lavender. NPC - Natural Product Communications 13: 1403-1417. 